\title{
Validation of using gene expression in mononuclear cells as a marker for hepatic cholesterol metabolism Dimple Aggarwal ${ }^{1}$, Hedley C Freake ${ }^{1}$, Ghada A Soliman², Amrita Dutta ${ }^{1}$ and Maria-Luz Fernandez*1
}

Address: ${ }^{1}$ Department of Nutritional Sciences, University of Connecticut, Storrs, CT 06269, USA and 2Division of Metabolism, Endocrinology and Diabetes, Department of Internal Medicine, University of Michigan Medical School Ann Arbor, Michigan, 48109, USA

Email: Dimple Aggarwal - dimple.aggarwal@spcorp.com; Hedley C Freake - hedley.freake@uconn.edu; Ghada A Soliman - gsoliman@med.umich.edu; Amrita Dutta - amrita.dutta@uconn.edu; Maria-Luz Fernandez* - marialuz.fernandez@uconn.edu

* Corresponding author

Published: 15 August 2006

Lipids in Health and Disease 2006, 5:22 doi:10.1186/1476-5IIX-5-22

This article is available from: http://www.lipidworld.com/content/5///22

(c) 2006 Aggarwal et al; licensee BioMed Central Ltd.

This is an Open Access article distributed under the terms of the Creative Commons Attribution License (http://creativecommons.org/licenses/by/2.0), which permits unrestricted use, distribution, and reproduction in any medium, provided the original work is properly cited.
Received: 14 July 2006

Accepted: 15 August 2006

\begin{abstract}
HMG-CoA reductase and the LDL receptor are ubiquitously expressed in major tissues. Since the liver plays a major role in regulating circulating $L D L$, it is usually of interest to measure the effects of drug or dietary interventions on these proteins in liver. In humans, peripheral blood mononuclear cells have been used as a surrogate for liver to assess regulation of these genes, although there is concern regarding the validity of this approach. The purpose of this study was to evaluate the relationship between liver and mononuclear cell expression of HMG-CoA reductase and the LDL receptor in guinea pigs, a well established model for human cholesterol and lipoprotein metabolism. We extracted RNA from liver and mononuclear cells of guinea pigs from a previous study where the effects of rapamycin, an immunosuppresant drug used for transplant patients, on lipid metabolism were evaluated. Guinea pigs were assigned to three different diets containing the same amount of fat $(15 \mathrm{~g} / \mathrm{l} 00 \mathrm{~g})$ and cholesterol $(0.08 \mathrm{~g} / 100 \mathrm{~g})$ for a period of 3 weeks. The only difference among diets was the concentration of rapamycin: $0,0.0028$ or $0.028 \mathrm{~g} / 100 \mathrm{~g}$. There were no differences in plasma LDL cholesterol (LDL-C) among groups. Values were $78.4 \pm 14.3,65.8 \pm$ 17.2 and $68.4 \pm 45.4 \mathrm{mg} / \mathrm{dL}(P>0.05)$ for guinea pigs treated with 0 , low or high doses of rapamycin, respectively. The mRNA abundance for the LDL receptor and HMG-CoA reductase was measured both in liver $(n=30)$ and mononuclear cells $(n=22)$ using reverse transcriptase PCR. In agreement with the finding of no changes in plasma LDL-C, there were also no differences for the expression of HMG-CoA reductase or the LDL receptor among groups. However, a positive correlation was found between liver and mononuclear cells for both HMG-CoA reductase $(r=0.613, P<0.01)$ and the LDL receptor $(r=0.622, P<0.01)$. These correlations suggest that monocytes can be used in humans as an index for liver to assess diet and drug effects on the expression of HMG-CoA reductase and the LDL receptor.
\end{abstract}




\section{Findings}

Although cholesterol is an extremely important biological molecule with a major role in membrane structure as well as a precursor for the synthesis of steroid hormones and bile acids, excessive cholesterol, is involved in atherosclerotic lesions. Therefore, a balance must be maintained between cholesterol absorption, excretion and endogenous cholesterol synthesis. In this regard, the liver plays an important role in controlling the amount and composition of circulating LDL cholesterol (LDL-C) levels [1]. For example, under increased dietary cholesterol challenge, the LDL receptor, responsible for the uptake of LDL-C is downregulated [1]. Under similar conditions the rate limiting enzyme of cholesterol synthesis, 3-hydroxy3methyl glutaryl Coenzyme A (HMG-CoA) reductase is also downregulated [2] and at the same time cholesterol $7 \alpha$-hydroxylase (CYP7), responsible for catabolism of cholesterol as bile, is upregulated [3] as part of a compensatory mechanism in the liver. Experiments aimed towards the evaluation of drug or dietary interventions conducted in animals rely highly on the liver to evaluate major mechanisms responsible for alterations of plasma lipids. Unfortunately, the liver is not readily accessible during clinical trials. In various human studies, mononuclear cells have been reported to be used as surrogates for liver to estimate hepatic expression of various genes involved in cholesterol metabolism; however, the extent to which mononuclear cells reflect hepatic expression can be questioned $[4,5]$. Major proteins involved in cholesterol metabolism present in liver are also ubiquitously expressed in other tissues. HMG-CoA reductase and the LDL receptor are clear examples of such proteins. The main purpose of this study was the validation of gene expression in mononuclear cells as marker of hepatic cholesterol metabolism. Guinea pigs were used as the animal model because of their well documented similarities to humans in terms of cholesterol and lipoprotein metabolism [6]. In addition, previous studies performed in our laboratory have reported that guinea pigs serve as a good model for evaluating diet and drugs affecting lipid metabolism $[6,7]$. We used liver and mononuclear cells that were available from guinea pigs treated with rapamycin where no effects were seen on plasma LDL cholesterol. Thus we were not expecting an effect on LDL receptor or HMG-CoA reductase expression due to treatment [8].

\section{Methods}

\section{Diets and animals}

Diets were designed to meet the nutritional requirements of guinea pigs. All diets contained the same amount of fat, $15 \mathrm{~g} / 100 \mathrm{~g}$ and of dietary cholesterol, $0.08 \mathrm{~g} / 100 \mathrm{~g}$ and they only varied in the amount of rapamycin $(0,0.0028$ or $0.028 \mathrm{~g} / 100 \mathrm{~g}$ ). Thirty male guinea pigs (Sprague Dawley, Elm Hills Lab) ( $\mathrm{n}=10$ per group) were used for this experiment [8]. Guinea pigs consumed the diets for 3 weeks and diets were weighed daily to determine the amount of food consumed. Guinea pigs were deprived of food overnight and sacrificed by heart puncture after isoflurane anesthesia. Blood was obtained via heart puncture. After euthanasia, the liver was removed, wrapped in labeled, precooled aluminum foil, and then snap frozen in liquid nitrogen and stored immediately at $-80^{\circ} \mathrm{C}$ until the day of RNA extraction. Experimental protocols were approved by the University of Connecticut Institutional Animal Care and Use Committee.

\section{Mononuclear cell isolation}

Mononuclear cells were isolated from whole blood by centrifugation on a Ficoll gradient by the method of Boyum [9]. Briefly, $20 \mathrm{ml}$ blood was diluted with $10 \mathrm{ml}$ HBSS without $\mathrm{Ca}^{2+}$ and $\mathrm{Mg}^{2+}$, layered over $10 \mathrm{ml}$ Histopaque $^{\circledR} 1077$ and centrifuged at $500 \times \mathrm{g}$ for 30 minutes. The mononuclear cell interface was removed, and washed with HBBS and centrifuged at $600 \times \mathrm{g}$ for 10 minutes twice. The cell pellet was resuspended in $200 \mu \mathrm{l}$ Tris buffer (10 mM Tris, $150 \mathrm{mM} \mathrm{NaCl}, 1 \mathrm{mM} \mathrm{CaCl}_{2}, \mathrm{pH} 7.4$ ), and kept at $-80^{\circ} \mathrm{C}$ until RNA was extracted.

\section{RNA extraction}

Total RNA was extracted from the liver and mononuclear cells by the method of Chomczynski et al. [10]. To check the integrity of the extracted RNA, samples were electrophoresed through a $1 \%$ agarose gel at $125 \mathrm{~V}$ for $45 \mathrm{~min}$ utes. Two clear sharp bands represented $28 \mathrm{~S}$ and $18 \mathrm{~S}$ ribosomal fraction of RNA (data not shown).

\section{RNA quantification}

HMG-CoA reductase and LDL receptor mRNA abundance were determined from liver and mononuclear cell extracts using a semi-quantitative RT-PCR method adapted from that of Powell and Kroon [11]. The RT-PCR reaction was carried out using a Qiagen One Step RTPCR kit in a Gene Amp ${ }^{\circledast}$ PCR system 9700 (Applied Biosystems, CA) thermal cycler. Oligonucleotide primers used for amplification were those used for HMG-CoA reductase [12] and the LDL receptor in humans [13]. The primers used for $\beta$-actin, a house keeping gene, were taken from guinea pig sequences and have been previously reported [14]. The approximate size of each reaction product is as follows: HMG-CoA reductase : $255 \mathrm{bp}$, LDL receptor : 240 , and $\beta$ actin: 220 bp. $\beta$-Actin was used as a control in all reactions. The reaction mixture contained $1.0 \mu \mathrm{g}$ of total RNA. Amplification was carried out at an annealing temperature of $56^{\circ}$ for 35 cycles for HMG-CoA reductase, $56^{\circ}$ for LDL receptor for 32 cycles, $56^{\circ}$ for $\beta$-actin for 27 cycles. Ten $\mu \mathrm{L}$ of each reaction mixture was size fractionated by electrophoresis in a $1 \%$ agarose gel, in 1\% Tris-borate/EDTA buffer. Bands were visualized by staining with ethidium bromide. The amplified RT-PCR products were electrophoresed through a $1 \%$ agarose gel at $125 \mathrm{~V}$ for $45 \mathrm{~min}$ - 

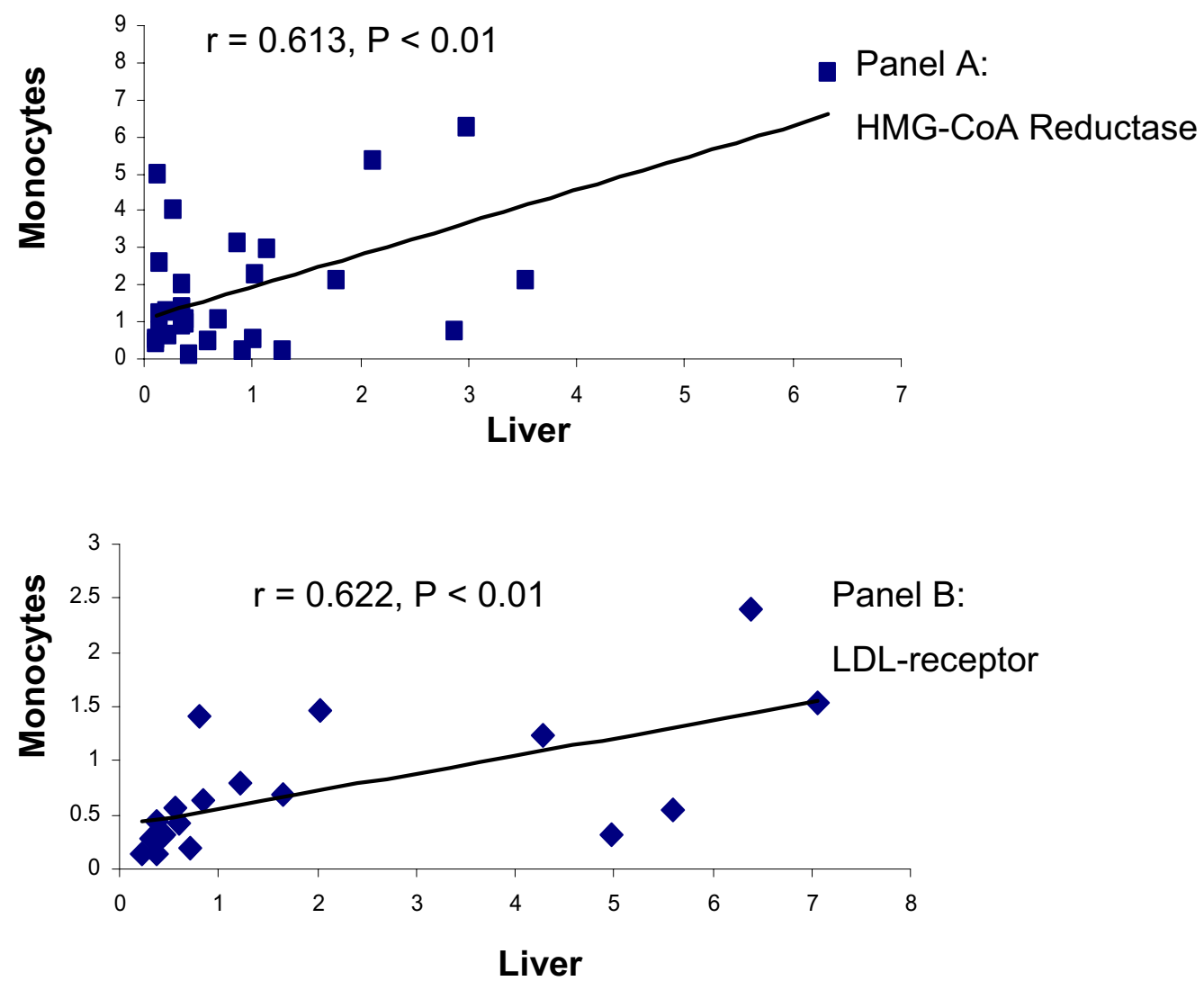

\section{Figure I}

(Panel A) Correlation between liver and mononuclear cells for the expression of HMG-CoA reductase $(n=30)$. (Panel B) Correlation between liver and mononuclear cells for the expression of the LDL receptor $(n=22)$.

utes. Band sizes were identified using a DNA molecular marker.

Products were then quantified by measuring the relative band intensity using The Image J program (NIH). Band intensities were corrected based on the $\beta$-actin signal.

\section{Results}

There were no differences in plasma cholesterol among groups although there were individual differences in guinea pigs ranging from 34 to $173 \mathrm{mg} / \mathrm{dL}$. Mean values were $78.4 \pm 14.3,65.8 \pm 17.2$ and $68.4 \pm 45.4 \mathrm{mg} / \mathrm{dL}$ for the 0 , low and high rapamycin, respectively. In agreement with these data, there were no significant differences in the expression of the LDL receptor or HMG-CoA reductase among groups. The relative values for mononuclear cell HMG-CoA reductase expression were $2.61 \pm 2.33,1.95 \pm$ 1.85 and $1.39 \pm 1.52$ for control, low and high rapamacyn, respectively while the corresponding values for the liver were $1.54 \pm 1.90,0.81 \pm 0.91$ and $0.77 \pm 1.04$. Similarly, there was no treatment effect for the LDL receptor.
The relative values for 0 , low and high rapamycin in the liver were $1.13 \pm 1.24,4.6 \pm 4.96$ and $2.09 \pm 1.91$ and the corresponding values in the mononuclear cells were 1.21 $\pm 0.75,1.64 \pm 2.24$, and $1.62 \pm 3.33$. A strong positive correlation was found between the expression of $\mathrm{HMG}-\mathrm{CoA}$ reductase in the liver and in the mononuclear cells $(\mathrm{r}=$ $0.613, \mathrm{P}<0.01$ ) (Figure 1, panel A). The expression of LDL receptor in liver and mononuclear cells were also positively correlated $(\mathrm{r}=0.623, \mathrm{P}<0.01)$ (Figure 1 , Panel B).

\section{Discussion}

The current study provided an opportunity to study gene expression in both liver and mononuclear cells to validate mononuclear cells as surrogates of hepatic expression of HMG-CoA reductase and the LDL receptor.

The liver being a biologically active organ is often harvested to study the activity and expression of various proteins affected by dietary interventions or drug treatment $[2,8]$. Analysis of hepatic enzymes or receptors is feasible 
in animal studies but it becomes a limiting factor in human studies thus the use of mononuclear cells becomes a desirable option. However, there has always been a concern whether the generated data truly represent hepatic activity. However, there is one study conducted in humans which demonstrated that the mechanisms which regulate mRNA levels in liver and mononuclear cells are similar and suggested that mononuclear cells can be used to predict HMG-CoA reductase and LDL receptor mRNA levels in liver [15]. The functionality of the LDL receptor has been shown in mononuclear cells in which the concentration of both protein and mRNA were evaluated in subjects who had been treated with plant stanol [16]. Another study reported an increased expression of HMGCoA reductase for human mononuclear cells in subjects consuming $10 \mathrm{~g} / \mathrm{d}$ of psyllium for one month [4], results which are in agreement with hepatic HMG-CoA reductase activity being up-regulated in guinea pigs after psyllium consumption [17]. In addition, previous studies in our laboratory have shown that the decreases in LDL-C observed following a weight reduction program were correlated with increased expression of the LDL receptor in human mononuclear cells [5].

The positive correlation found between the expression of the LDL receptor and HMG-CoA reductase in liver and mononuclear cells in the current study supports the measurement of the expression of these two ubiquitously distributed proteins in human mononuclear cells as a surrogate for hepatic cholesterol metabolism.

\section{Abbreviations}

HMG-CoA: 3-hydroxy-3methyl glutaryl Coenzyme A; LDL-C: LDL cholesterol; RCT: reverse cholesterol transport

\section{Competing interests}

The author(s) declare that they have no competing interests.

\section{Authors' contributions}

DA did the assays, wrote the manuscript and participated in the interpretation of data; GS: assisted in data interpretation and critical evaluation of manuscript; AD: assisted in the molecular techniques; HF: developed the molecular techniques and assisted in data interpretation and MLF designed the experiment, evaluated the results, interpreted the data and participated in manuscript preparation.

\section{Acknowledgements}

Supported in part by NIH-KOI-DK60654 award to GS

\section{References}

I. Meddings JB, Spady DK, Dietscy JM: Kinetic characteristics and mechanisms of regulation of receptor-dependent and recep- tor-independent LDL transport in the liver of different animal species and humans. Am Heart J 1987, I I 3:475-48I.

2. Lin ECK, Fernandez ML, McNamara DJ: Dietary cholesterol and fat quantity interact to affect cholesterol metabolism in guinea pigs. J Nutr 1992, 1 20:2019-2022.

3. Nguyen L, Guorong X, Shefer S, Tint G, Batta A, Salen G: Comparative regulation of hepatic sterol 27 -hydroxylase and cholesterol alpha-hydroxylase activities in the rat, guinea pig and rabbit: Effects of cholesterol and bile acids. Metabolism 1999, 48: $1542-1548$.

4. Vega-Lopez S, Freake HC, Fernandez ML: Sex and hormonal status modulate the effects of psyllium on plasma lipids and monocyte gene expression in humans. J Nutr 2003, 133:67-70.

5. Patalay M, Lofgren I, Freake HC, Koo SI, Fernandez ML: The lowering of plasma lipids following a weight reduction program is related to increased expression of the LDL receptor and lipoprotein lipase. J Nutr 2005, I35:735-739.

6. Fernandez ML: Guinea pigs as models for cholesterol and lipoprotein metabolism. J Nutr 200I, I3 1:10-20.

7. West KL, Fernandez ML: Guinea pigs as models to study the hypercholesterolemic effects of drugs. Cardiovasc Drug Rev 2004, 22:55-70.

8. Aggarwal D, Fernandez ML, Soliman G: Rapamycin, an mTOR inhibitor, disrupts triglyceride metabolism in guinea pigs. Metabolism 2006, 55:794-802.

9. Boyum A: Isolation of mononuclear cells and granulocytes from human blood. Scand J Clin Lab Invest 1968, 97:77-89.

10. Chomczynski P, Sacchi N: Single-step method of RNA isolation by acid guanidinium thiocyanate-phenol-chloroform extraction. Anal Biochem 1987, 162:156-159.

II. Powell E, Kroon P: Measurement of mRNA by quantitative PCR with a nonradioactive label. J Lipid Res 1992, 33:609-6I4.

12. Wang A, Doyle M, Mark D: Quantitation of mRNA by the polymerase chain reaction. Proc Natl Acad Sci USA 1989, 86:97|7-972I.

13. Luskey K, Stevens B: Human-3-hydroxy-3-methylglutaryl coenzyme A reductase. Conserved domains responsible for catalytic activity and sterol-regulated degradation. J Biol Chem 1985, 260: 1027I-10277.

14. West KL, McGrane MM, Odon D, Kelley BL, Fernandez ML: SC-435, an ileal apical sodium-codependent bile $a$ and lipoprotein metabolism in guinea pigs. J Nutr Biochem 2005, 16:722-728.

15. Powell E, Kroon P: Low density lipoprotein receptor and 3hydroxy-3-Methylglutaryl coenzyme $A$ reductase gene expression in human mononuclear leukocytes is regulated coordinately and parallels gene expression in human liver. J Clin Invest 1994, 93:2168-2174.

16. Plat J, Mensik RP: Effects of plant stanol esters on LDL receptor protein expression and on LDL receptor and HMG-CoA reductase mRNA expression in mononuclear blood cells of healthy men and women. FASEB J 2002, 16:258-260.

17. Fernandez ML: Distinct mechanisms of plasma LDL lowering by dietary soluble fiber: Specific effects of pectin, guar gum and psyllium. J Lipid Res 1995, 36:2394-2404.

Publish with Bio Med Central and every scientist can read your work free of charge

"BioMed Central will be the most significant development for disseminating the results of biomedical research in our lifetime."

Sir Paul Nurse, Cancer Research UK

Your research papers will be:

- available free of charge to the entire biomedical community

- peer reviewed and published immediately upon acceptance

- cited in PubMed and archived on PubMed Central

- yours - you keep the copyright

Submit your manuscript here:

http://www.biomedcentral.com/info/publishing_adv.asp
BioMedcentral 